\title{
PENGEMBANGAN PENDIDIKAN AGAMA ISLAM MENGGUNAKAN METODE INQUIRY
}

\author{
KISMATUN \\ SMP N 1 Limpung \\ e-mail: kismatunazza@gmail.com
}

\begin{abstract}
ABSTRAK
Penelitian ini bertujuan untuk melakukan pengembangan pembelajaran bagi mata pelajaran Pendidikan Agama Islam berbasis penalaran dan pemecahan masalah. Metode inquiry adalah pembelajaran berbasis penalaran dan pemecahan masalah yang seharusnya diaktualisasikan dalam rangka mengembangkan pembelajaran Pendidkan Agama Islam. Pasalnya, Pendidikan Agama Islam berada di tempat strategis dalam pembentukan manusia secara utuh untuk mengembangkan akal, pengetahuan, kecerdasan, keterampilan, akhlak mulia, dan kepribadian. Di tengah tantangan zaman, guru Agama Islam diharapkan memiliki inovasi-inovasi baru terkait dengan pembelajaran. Sementara itu, di tengah masyarakat sendiri masih banyak kritikkritik yang ditujukan pada pelaksanaan pembelajaran agama Islam, karena cenderung pada hafalan, dan kurang penalaran. Bahkan, banyak penelitian menunjukkan bahwa, mata pelajaran pendidikan Agama Islam hanyalah mata pelajaran sampingan yang tidak penting. Pada akhirnya, penelitian ini menemukan bahwa, metode inquiry merangsang murid untuk berpikir, menganalisa suatu persoalan, hingga menemukan pemecahannya. Inquiry learning menekankan kepada pengembangan aspek kognitif, afektif dan psikomotor secara seimbang yang dapat memberi ruang kepada siswa untuk belajar sesuai gaya mereka.
\end{abstract}

Kata Kunci: Pendidikan Agama Islam, Inquiry, konvensional, konstruktivisme

\section{ABSTRACT}

This study aims to develop learning for Islamic education subjects based on reasoning and problem solving. The inquiry method is reasoning-based learning and problem solving that should be actualized in order to develop Islamic education learning, because Islamic education is in a strategic position in the formation of a complete human being to develop reason, knowledge, intelligence, skills, noble character, and personality. Based on the challenges of the times, Islamic Religion teachers are expected to have new innovations related to their learning. Meanwhile, in the community itself, there are many criticisms aimed at the implementation of Islamic religious learning, because it tends to memorize, and lacks reasoning. In fact, many studies show that, Islamic education are just secondary subjects that are not important. In the end, this study found that the inquiry method stimulates students to think, analyze a problem, and find a solution. Inquiry learning emphasizes the development of cognitive, affective and psychomotor aspects in a balanced manner which can provide space for students to learn according to their style.

Keywords: Islamic education, inquiry, conventional, constructivism

\section{PENDAHULUAN}

Pendidikan agama Islam memiliki tempat strategis pada semua tingkat pendidikan sebab bidang studi ini sangat penting dalam pembentukan manusia secara utuh, yaitu manusia yang berkembang akalnya, berwawasan ilmu pengetahuan yang tinggi, cerdas dan terampil, berakhlak mulia, berkepribadian, memiliki semangat kebangsaan dan kegotong-royongan. Di tengah tantangan zaman, guru agama Islam diharapkan memiliki inovasi-inovasi baru terkait dengan pembelajarannya. Sementara itu, di tengah masyarakat sendiri masih banyak kritikkritik yang ditujukan pada pelaksanaan pembelajaran agama Islam, misal pembelajaran PAI yang hanya cenderung pada hafalan saja, kurangnya penalaran dan argumentasi berpikir untuk masalah-masalah keagamaan, penghayatan nilai-nilai agama yang kurang, ukuran keberhasilan pendidikan agama juga masih sebatas formalitas saja, pendidikan agama belum dijadikan 
fondasi pendidikan karakter, dll.

Reid menegaskan bahwa tuntutan abad ke-21 mengharuskan pendidik untuk menjadi pembelajar profesional yang memiliki dampak kuat pada keterampilan dan pengetahuan guru dan prestasi siswa (Higgins, dkk, 2011: 11). Meskipun beberapa studi menunjukkan jika guru melakukan integrasi teknologi untuk mendukung pembelajaran, akan tetapi pada praktik lapangan pembelajaran hanya berpusat pada guru yang ada (Reinhardt, 2014: 3). Oleh karenanya, dibutuhkan aktualisasi pembelajaran inquiry yang diterapkan dalam semua pembelajaran, termasuk mata pelajaran Pendidikan Agama Islam.

Aktualisasi inquiri pada mata pelajaran Pendidikan Agama Islam memunculkan kreatifitas siswa, memberi kebebasan untuk mengemukakan pendapat secara lisan atau verbal, dan menimbulkan komunikasi dan kerja sama (Sariah, 2017: 107). Selain itu, jika guru menerapkan metode penelitian dalam suatu pembelajaran, maka siswa adalah pihal yang mendapatkan manfaat paling besar dari pembelajaran tersebut, baik dalam hal kedalaman pembelajaran atau pemahaman (Healey, 2005: 1). Dengan demikian, penelitian ini berusaha mengaktualisasikan pembelajaran inquiry dalam mata pelajaran Pendidikan Agama Islam, khususnya materi zakat. Aktualisasi pembelajaran inquiry dilaksanakan di SMP 1 Limpung dengan menggunakan langkah-langkah sebagai berikut: pertama, orientasi yaitu memberi pengetahuan dasar mengenai materi yang disampaikan; kedua, merumuskan masalah, yaitu siswa diberi paradoks realitas, lalu mereka merumuskan masalahnya; ketiga, hipotesis, yaitu siswa mengajukan kesimpulan sementara bertolak dari rumusan masalah yang ada; keempat, pengumpulan data, yaitu siswa melakukan investigasi guna dalam rangka pengumpulan data yang berguna untuk menjawab rumusan masalah; kelima, menguji hipotesis, yaitu siswa melakukan penilaian terhadap data dan hipotesis yang diajukan; keenam, menyimpulkan, yaitu siswa menyimpulkan berdasar data yang dikumpulkan, lalu memberi keputusan terhadap hipotesis yang diajukan. Dengan demikian, langkah-langkah ini diharapkan memberi hasil yang lebih baik dalam rangka pengembangan pembelajaran Pendidikan Agama Islam yang selama ini dianggap tidak penting.

\section{METODE PENELITIAN}

Jenis penelitian ini menggunakan penelitian kualitatif yang tergolong sebagai penelitian pustaka (library research). Penelitian ini ingin menyoal kembali mengenai model pembelajaran konvensional yang terbelakang dan tidak memberi pengaruh yang signifikan. Penelitian ini berusaha menawarkan solusi atas kejumudan model pembelajaran pendidikan Agama Islam melalui model pembelajaran inquiri. Dengan demikian, penelitian ini berusaha menawarkan hal baru dalam pendidikan Agama Islam untuk mencapai pendidikan Agama Islam yang komprehensif dan lebih efektif.

Data yang diperlukan dalam penelitian ini dikelompokkan menjadi dua, yaitu data primer dan sekunder. Data primer adalah data yang diperoleh dan dikumpulkan oleh sumber pertama (Prastowo, 2016: 204). Data primer penelitian ini adalah pustaka yang memberi ulasan mengenai teori pembelajaran inquiry dan thesis-thesis mengenai penelitian Agama Islam selama ini. Sedangkan data sekunder adalah data yang diperoleh bukan dari sumber pertama, namun sumber kedua, ketiga, dan seterusnya (Prastowo, 2016: 205). Data sekunder merupakan data pelengkap sekaligus pendukung data primer yang diperoleh melalui data yang terdapat dalam literatur kepustakaan seperti buku, jurnal, artikel, maupun internet. Selain itu data juga dapat diperoleh melalui sumber lainnya yang berkaitan dengan materi penulisan ini. Data sekunder dalam penelitian ini berupa dokumen-dokumen dan buku-buku yang berkaitan dengan pendidikan Agama Islam dan teori pembelajaran inquiry.

Dalam penelitian ini, penulis mendeskripsikan prinsip dasar, langkah-langkah, dan model pembelajaran inquiry. Sebagai bentuk aktualisasinya, penulis mencoba mengaplikasikan teori pembelajaran inquiry pada mata pelajaran pendidikan Agama Islam terkait dengan tema alQuran dan hadis, serta fiqh. Selain itu, penulis juga mendeskripsikan terkait dengan kelebihan dan kekurangan dari teori pembelajaran inquiry guna melihat teori ini secara lebih 
komprehensif. Pada akhirnya, penelitian ini dilakukan guna melakukan pengembangan pembelajaran mata pelajaran pendidikan Agama Islam yang mengalami kejumudan.

\section{HASIL DAN PEMBAHASAN}

Berikut adalah hasil penelitian berdasar study pustaka mengenai pengembangan pendidikan Agama Islam menggunakan metode inquiry:

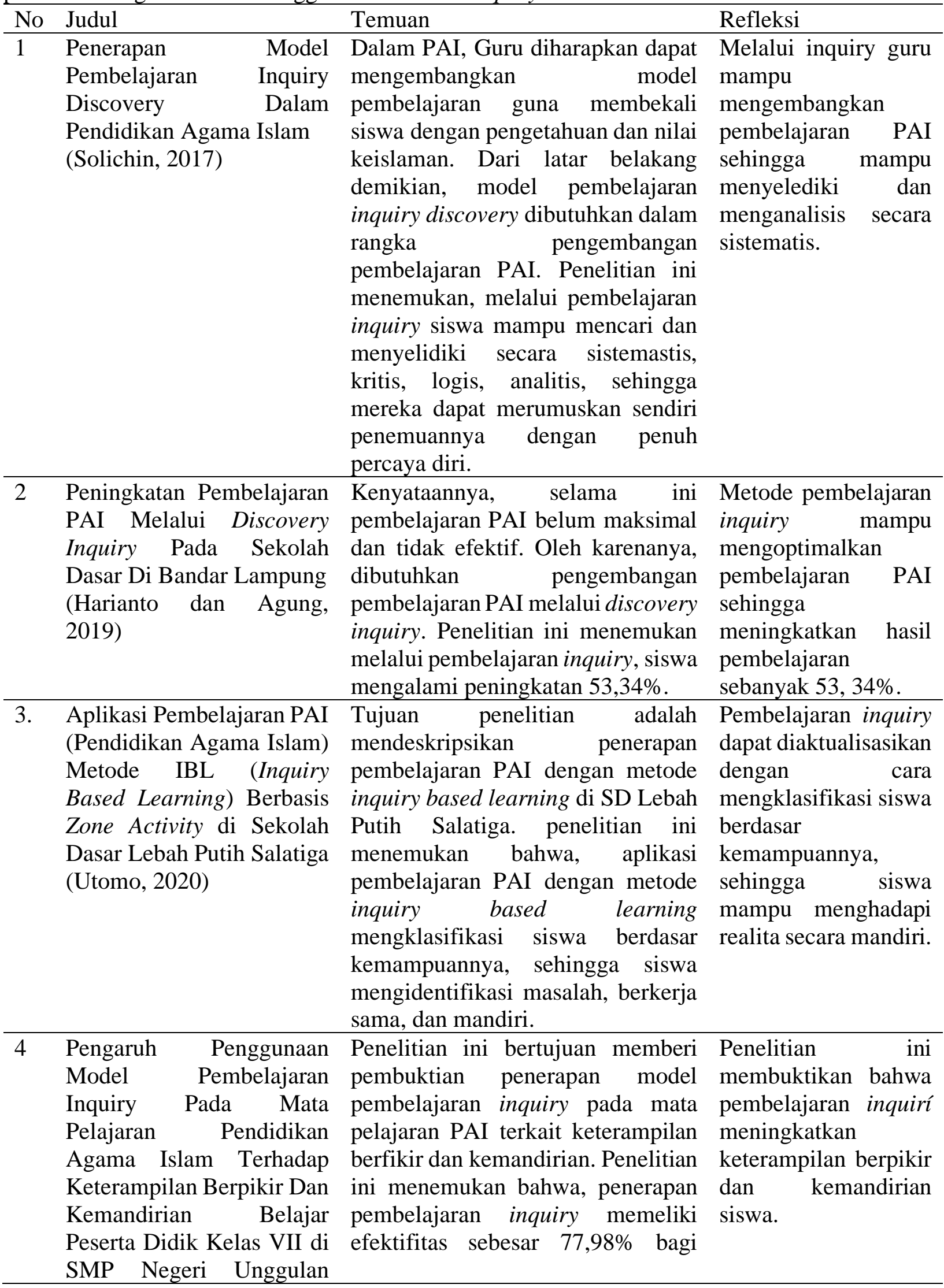




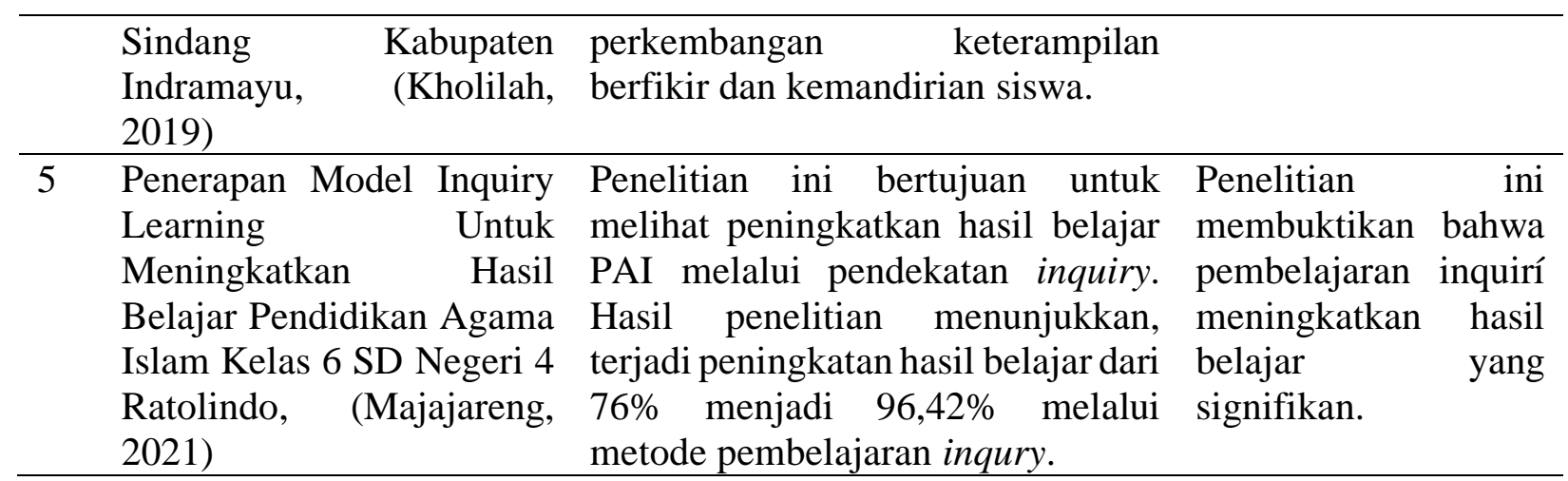

\section{Pembelajaran Inquiry}

Inquiry berasal dari bahasa inggris "inquiry", yang secara harfiah berarti penyelidikan atau pemeriksaan. Bisa juga dari kata "to inquire" yang berarti ikut serta atau terlibat, dalam mengajukan pertanyaan- pertanyaan, mencari informasi, dan melakukan penyelidikan (Suryani \& Agung, 2012: 119). Novak mengatakan bahwa inquiry merupakan suatu tindakan yang memerlukan usaha dari manusia untuk menjelaskan suatu masalah yang hendak diteliti (Novak, 1964: 25-28).

Carin dan Sund (1975) mengemukakan bahwa inquiry adalah proses investigasi masalah. Piaget mengemukakan bahwa, inquiry merupakan metode yang mempersiapkan peserta didik untuk melakukan eksperimen sendiri secara luas agar melihat apa yang terjadi, ingin melakukan sesuatu, mengajukan pertanyaan-pertanyaan, dan mencari jawabannya sendiri, serta menghubungkan penemuan yang satu dengan penemuan yang lain, membandingkan apa yang ditemukan peserta didik lain (Mulyasa, 2008: 108).

Newell (2003: 5) mendefinisikan Inquiry Based Learning sebagai proses yang menekankan minat siswa daripada mengikuti kurikulum tetap. Menekankan fokus inter disipliner yang luas daripada disiplin yang sempit, fokus berdasarkan disiplin, menggunakan sumber langsung, primer atau asli, daripada teks, ceramah, dan sumber sekunder; menekankan data dan materi yang dikembangkan oleh siswa daripada guru.

Metode inquiry ini berasal dari John Dewey yang mendefinisikan sebagai transformasi terkendali dari situasi tak tentu menjadi situasi menentu dalam pembeda konstituen untuk mengkonversi unsur-unsur situasi sebenarnya menjadi satu kesatuan (Won, 2009: 6). Maksud inquiry adalah memberi latihan kepada murid untuk berfikir, di mana ia menghindari membuat kesimpulan tergesa-gesa, menimbang kemungkinan dan pengambilan keputusan sampai terdapat bukti-bukti yang cukup (Muhaimin, 1996: 88).

Metode inquiry merupakan teknik atau cara yang digunakan guru untuk mengajar di depan kelas, adapun pelaksanaannya sebagai berikut: guru membagi tugas meneliti sesuatu masalah, siswa dibagi beberapa kelompok, dan masing-masing kelompok mendapat tugas tertentu. Kemudian mereka mempelajari, meneliti dan membahas tugasnya didalam kelompok. Setelah hasil kerja kelompok mereka mendiskusikan, kemudian baru didiskusikan dalam forum (Roestiyah, 1991: 75). Metode ini merangsang murid untuk berpikir, menganalisa suatu persoalan sehingga menemukan pemecahannya. Dalam bahasa Inggris disebut problem solving method (Djajadisastra, 1981: 19).

Cara penyampaian bahan pengajaran dalam metode ini yakni dengan memberi kesempatan kepada siswa untuk belajar mengembangkan potensi intelektualnya dalam jalinan kegiatan yang disusun sendiri untuk menemukan sesuatu sebagai jawaban yang meyakinkan terhadap permasalahan yang dihadapkan kepadanya melalui proses pelacakan data dan informasi serta pemikiran yang logis, kritis (teliti dalam menghadapi sesuatu) dan sistematis (teratur) (Slameto, 1993: 116).

Metode inquiry merupakan komponen penting dalam pembaruan pendidikan, Sebab, siswa didorong untuk belajar melalui keterlibatan aktif. Guru mendorong siswa untuk memiliki pengalaman dan melakukan percobaan yang memungkinkan mereka menemukan temuan 
mereka sendiri (Nurhadi \& Senduk, 2004). Dengan demikian, inquiry memberi kepadasiswa pengalaman belajar yang nyata dan kreatif. Siswa diharapkan mengambil inisiatif, di mana mereka dilatih untuk memecahkan masalah, membuat keputusan, dan memperoleh keterampilan, bahkan mereka bekerja sama mencari solusi terhadap masalah yang dihadapi.

Metode inquiry dalam proses belajar mengajar adalah strategi yang melibatkan siswa dalam tanya jawab, mencari informasi, dan melakukan penyelidikan (Sunaryo, 1989: 117). Inquiry merupakan teknik yang mempersiapkan peserta didik untuk melakukan eksperimen sendiri agar melihat apa yang terjadi, ingin melakukan sesuatu, mengajukan pertanyaanpertanyaan dan mencari jawabannya sendiri, serta bisa menghubungkan dengan penemuan yang lain, membandingkan apa yang ditemukannya dengan yang ditemukan peserta didik lainnya. Kemampuan tersebut sangat membantu dalam proses penyelidikan, eksplorasi, pencarian, penelitian, dan kajian (Carol dkk, 2007: 2).

Pembelajaran inquiry juga merupakan pembelajaran yang menyenangkan, dimana dalam prakteknya langsung pada lapangan dan bukan hanya teori, hal ini sebagaimana pendapat (Darmansyah: 2010) Hasil penelitian dalam dekade terakhir mengungkapkan belajar yang efektif, jika peserta didik dalam keadaan gembira. Kegembiraan dalam belajar telah terbukti memberikan efek yang luar biasa terhadap pencapaian hasil belajar peserta didik. Bahkan potensi kecerdasan intelektual yang selama ini menjadi "Primadona" sebagai penentu keberhasilan belajar, ternyata tidak sepenuhnya benar, kecerdasan emosional telah memberikan kontribusi yang signifikan terhadap efektivitas pembelajaran disamping kecerdasan intelektual (Darmansyah, 2010: 3-4.).

Metode ini mengembangkan kemampuan berfikir dengan adanya kesempatan untuk mengobservasi problem mengumpulkan data, menganalisa data, menyusun suatu hipotesa, mencari hubungan data yang hilang dari data yang telah terkumpul untuk kemudian menarik kesimpulan yang merupakan hasil pemecahan masalah tersebut. Berdasarkan penjelasan di atas, dapat disimpulkan bahwa metode inquiry adalah metode yang memberi kesempatan siswa untuk menemukan sendiri pengetahuan yang belum diketahui.

\section{Prinsip dan Langkah-langkah Pembelajaran Inquiry}

Berikut merupakan prinsip inquiry learning: a. berbasis paradigma konstruktivisme, $b$. pengetahuan dibangun berdasarkan pengalaman hidup, c. pengetahuan bersifat pribadi, $d$. pembelajaran aktif, tidak pasif, e. pembelajaran otentik menggunakan situasi dan masalah nyata, f. lebih kualitatif daripada kuantitatif, fokus terhadap prosesnya, g. memberikan fleksibilitas, h. fokus siswa berpusat pada kebutuhan, kemampuan dan minat, i. akuntabilitas siswa untuk belajar, j. siswa diarahkan, k. penilaian dilakukan sebelum, selama dan sesudah pembelajaran, 1. kurikulum didasarkan pada tujuan dan tujuan yang diidentifikasi oleh siswa, m. belajar itu dinamis, cair, dan mengalir (Wells, 2011: 49).

Sebelum melaksanakan pembelajaran menggunakan metode inquiry, guru harus memastikan bahwa siswa siap secara mental dan konseptual untuk pembelajaran, guru harus hati-hati merancang model inquiry yang tepat untuk memaksimalkan efektivitasnya. Penting bagi guru untuk merencanakan pembelajaran sesuai dengan kurikulum dan kemampuan siswa. Selain itu, guru harus menyesuaikan pembelajaran inquiry dengan rentang waktu sesuai langkah-langkah yang dianjurkan agar proses pembelajaran berlangsung dengan baik (Chu, dkk, 2017: 135). Secara umum, langkah-langkah pembelajaran Inquiry Learning dapat mengikuti langkah-langkah sebagai berikut:

a. Orientasi

Langkah orientasi adalah langkah untuk membina suasana atau iklim pembelajaran yang responsif. Pada langkah ini guru mengondisikan siswa agar siap melaksanakan proses pembelajaran. Berbedan dengan tahap preparation, guru merangsan dan mengajak siswa untuk berpikir memecahkan masalah. Beberapa hal yang dilakukan dalam tahap ini yaitu mdnjdlaskan topik, tujuan dan hasil yang ingin dicapai; menjelaskan pokok-pokok kegiatan yang harus dilakukan oleh siswa untuk mencapai tujuan; menjelaskan topik dan kegiatan 
belajar (Sanjaya, 2011: 201).

b. Merumuskan masalah

Merupakan langkah yang membawa siswa pada suatu persoalan yang mengandung tekateki. Persoalan yang disajikan adalah persoalan yang menantang siswa untuk berpikir memecahkan teka- teki itu. Dalam hal ini, siswa didorong untuk mencari jawaban yang tepat. Proses mencari jawaban itulah yang penting dalam pembelajaran inquiry ini. Sebab dalam proses itu siswa akan memperoleh pengalaman yang sangat berharga sebagai upaya mengembangkan mental melalui proses berpikir (Sanjaya, 2011: 202).

c. Mengajukan hipotesis

Hipotesis adalah jawaban sementara dari suatu permasalahan yang sedang dikaji. Sebagai jawaban sementara, hipotesis perlu diuji kebenarannya. Salah satu cara yang dapat dilakukan oleh guru untuk mengembangkan kemampuan berhipotesis anak adalah dengan mengajukan berbagai pertanyaan yang dapat mendorong siswa untuk dapat merumuskan jawaban sementara atau berbagai kemungkinan dari suatu permasalahan yang dikaji (Sanjaya, 2011: 203).

d. Mengumpulkan data

Merupakan aktivitas menjaring informasi yang dibutuhkan untuk menguji hipotesis yang diajukan. Dalam strategi belajar inquiry, mengumpulkan data adalah proses mental yang sangat penting dalam pengembangan intelektual. Tugas guru dalam proses ini adalah mengajukan pertanyaan yang dapat mendorong siswa untuk berpikir mencari informasi yang dibutuhkan (Sanjaya, 2011: 204).

e. Menguji hipotesis

Yakni proses menentukan jawaban yang dianggap diterima sesuai dengan data atau informasi yang diperoleh berdasarkan pengumpulan data. Hal yang terpenting dalam menguji hipotesis adalah mencari tingkat keyakinan siswa atas jawaban yang diberikan (Sanjaya, 2011: 205).

f. Merumuskan kesimpulan

Merumuskan kesimpulan adalah proses mendeskripsikan temuan yang diperoleh berdasarkan hasil pengujian hipotesis. Sering terjadi, sebab banyaknya data yang diperoleh, menyebabkan kesimpulan yang dirumuskan tidak fokus terhadap masalah yang hendak dipecahkan. Oleh karena itu, sebaiknya guru menunjukkan data mana yang relevan (Sanjaya, 2011: 205).

\section{Model-model Pembelajaran Inquiry}

Beberapa macam model pembelajaran inquiry (Inquiry Learning) yang dikemukakan oleh Sund dan Trowbridge diantaranya:

a. Guide Inquiry

Pembelajaran inquiry terbimbing yaitu suatu model pembelajaran inquiry yang dalam pelaksanaannya guru menyediakan bimbingan atau petunjuk cukup luas kepada siswa. Sebagian perencanaannya dibuatkan oleh guru, siswa tidak merumuskan problem atau masalah. Guru tidak melepas begitu saja kegiatan-kegiatan yang dilakukan oleh siswa. Inquiry terbimbing biasanya digunakan terutama bagi siswa yang belum berpengalaman belajar dengan pendekatan inquiry (Hamruni, 2009: 144).

b. Modified Inquiry

Model ini memiliki ciri yaitu guru hanya memberikan permasalahan tersebut melalui pengamatan, percobaan, atau prosedur penelitian untuk memperoleh jawaban. Di samping itu, guru merupakan narasumber yang tugasnya hanya memberikan bantuan yang diperlukan untuk menghindari kegagalan dalam memecahkan masalah (Hamruni, 2009: 144).

c. Free Inquiry

Pada model ini siswa harus mengidentifikasikan dan merumuskan macam-macam problema yang dipelajari dan dipecahkan. Jenis model inquiry ini lebih bebas daripada kedua jenis 
inquiry sebelumnya (Hamruni, 2009: 145).

d. Inquiry Role Approach

Model pembelajaran inquiry pendekatan peranan ini melibatkan siswa dalam tim-tim yang masing-masing terdiri atas empat orang untuk memecahkan masalah yang diberikan. Masing-masing anggota memegang peranan yang berbeda, yaitu sebagai koordinator tim, penasehat teknis, pencatat data dan evaluator proses (Hamruni, 2009: 145).

e. Invitation Into Inquiry

Model inquiry jenis ini siswa dilibatkan dalam proses pemecahan masalah dengan cara-cara yang ditempuh para ilmuwan, seperti merancang eksperimen, merumuskan hipotesis, menentukan sebab akibat, menginterpretasikan data, membuat grafik, menentukan peranan diskusi dan kesimpulan dalam merencanakan penelitian, dan memahami bagaimana kesalahan eksperimental dapat dikurangi atau diperkecil (Hamruni, 2009: 146).

f. Pictorial Riddle

Pada model ini merupakan metode mengajar yang dapat mengembangkan motivasi dan minat siswa dalam diskusi kelompok kecil atau besar, gambar, peragaan, atau situasi sesungguhnya dapat digunakan untuk meningkatkan cara berfikir kritis dan kreatif para siswa. Biasanya, suatu riddle berupa gambar di papan tulis, poster, atau diproyeksikan dari suatu transparansi, kemudian guru mengajukan pertanyaan yang berhubungan dengan riddle itu (Hamruni, 2009: 146).

g. Synectics Lesson

Model ini lebih memusatkan keterlibatan siswa untuk membuat berbagai macam bentuk kiasan supaya dapat membuka intelegensinya dan mengembangkan kreatifitasnya. Hal ini dapat dilaksanakan karena kiasan dapat membantu siswa dalam berfikir untuk memandang suatu masalah sehingga dapat menunjang ide- ide kreatif (Hamruni, 2009: 146).

h. Value Clarification

Siswa lebih difokuskan pada pemberian kejelasan tentang suatu tata aturan atau nilai-nilai pada suatu proses pembelajaran (Hamruni, 2009: 146).

\section{Keunggulan dan Kelemahan Inquiry Learning}

Inquiry learning merupakan strategi pembelajaran yang banyak dianjurkan. Berikut merupakan keunggulan pembelajaran inquiry:

a. Inquiry learning merupakan strategi pembelajaran yang menekankan kepada pengembangan aspek kognitif, afektif dan psikomotor secara seimbang sehingga pembelajaran menggunakan strategi ini dianggap lebih bermakna (Sanjaya, 2011: 208).

b. Inquiry learning dapat memberikan ruang kepada siswa untuk belajar sesuai gaya mereka (Sanjaya, 2011: 208).

c. Inquiry learning merupakan strategi yang dianggap sesuai dengan perkembangan psikologi belajar modern yang menganggap belajar adalah proses perubahan tingkah laku berkat adanya pengalaman (Sanjaya, 2011: 208).

d. Keuntungan lain adalah strategi pembelajaran ini dapat melayani kebutuhan siswa yang memiliki kemampuan di atas rata-rata. Artinya, siswa yang memiliki kemampuan belajar bagus tidak akan terhambat oleh siswa yang lemah dalam belajar (Sanjaya, 2011: 208).

Selain memiliki keunggulan, inquiry learning juga mempunyai kelemahan, diantaranya:

a. Jika inquiry learning digunakan sebagai strategi pembelajaran, maka akan sulit mengontrol kegiatan dan keberhasilan siswa (Sanjaya, 2011: 208).

b. Perencanaan pembelajaran dalam strategi ini sulit dilakukan sebab terbentur dengan kebiasaan siswa dalam belajar (Sanjaya, 2011: 208).

c. Kadang-kadang dalam mengimplementasikannya memerlukan waktu yang panjang, sehingga guru sering mengalami kesulitan dalam menyesuaikan dengan waktu yang telah ditentukan (Sanjaya, 2011: 208).

d. Selama kriteria keberhasilan ditentukan oleh kemampuan siswa dalam menguasai materi pelajaran, maka inquiry learning akan sulit diimplementasikan oleh setiap guru (Sanjaya, 


\section{Kesulitan Implementasi Pembelajaran Inquiry}

Inquiry learning merupakan salah satu strategi pembelajaran yang dianggap baru di Indonesia. Hal tersebut membuat strategi ini mengalami kesulitan dalam penerapannya, yaitu: pertama, inquiry learning merupakan strategi pembelajaran yang menekankan pada proses berpikir yang bersandarkan kepada dua sayap yang sama pentingnya, yaitu proses belajar dan hasil belajar. Selama ini guru yang sudah terbiasa dengan pola pembelajaran sebagai proses penyampaian informasi yang lebih menekankan pada hasil belajar, banyak yang merasa keberatan untuk merupah pola mengajarnya. Bahkan ada guru yang menganggap inquiry learning sebagai strategi yang tidak mungkin dapat diterapkan karena tidak sesuai dengan budaya dan sistem pendidikan di Indonesia (Sanjaya, 2011: 207).

Kedua, sejak lama tertanam dalam budaya belajar siswa bahwa belajar pada dasarnya menerima materi pelajaran dari guru, dengan demikian bagi mereka guru adalah sumber belajar yang utama. Sebab budaya belajar seperti itu sudah terbentuk menjadi kebiasaan, maka akan sulit mengubah pola belajar mereka dengan menjadikan belajar sebagai proses berpikir. Mereka akan sulit diajak untuk memecahkan suatu persoalan, bertanya, demikian pula dalam menjawab pertanyaan. Mereka akan kesuliatan menjawab pertanyaan meskipun pertanyaan tersebut sangat sederhana. Biasanya siswa akan memerlukan waktu cukup lama untuk merumuskan suatu jawaban pertanyaan (Sanjaya, 2011: 207).

Ketiga, berhubungan dengan sistem pendidikan kita yang dianggap tidak konsisten. Misal, sistem pendidikan menganjurkan bahwa proses pembelajaran sebaiknya menggunakan pola pembelajaran yang dapat mengembangkan kemampuan berpikir melalui pendekatan student active learning atau yang kita kenal dengan CBSA, namun dilain pihak, sistem evaluasi yang masih digunakan misalnya sistem ujian akhir nasional (UAN) berorientasi pada pengembangan aspek kognitif. Tentu saja hal ini dapat menambah kebingungan guru sebagai pelaksana di lapangan. Apakah akan melaksanakan pola pembelajaran dengan inquiry sebagai strategi pembelajaran yang menekankan pada proses belajar, atau akan mengembangkan pola pembelajaran yang diarahkan agar siswa dapat mengerjakan atau menjawab soal-soal hafalan (Sanjaya, 2011: 207).

\section{Implementasi Pembelajaran Inquiry dalam Pendidikan Agama Islam}

Metode inquiry dapat digunakan hampir di seluruh mata pelajaran, salah satunya PAI. Mengenai aktualisasi, penulis mengambil contoh mengenai tema zakat yang dapat diilustrasikan sebagai berikut: pertama adalah orientasi, yaitu guru membuka pembelajaran, lalu menjelaskan definsi zakat, ruang lingkup, macam, manfaat, orang yang berhak menerima zakat, manfaat zakat, dan pekerjaan atau harta yang wajib dizakati. Adapun tugas siswa adalah memperhatikan penjelasan guru. Berdasar aktualisasi peneliti di kelas, fase orientasi ini mudah dijalani dan siswa menikmatinya.

Kedua, merumuskan masalah, yaitu peneliti menyajikan masalah kepada siswa untuk dicari solusinya, misalnya pertanyaan mengenai perbedaan zakat dan sedekah, alasan seorang muslim harus mengeluarkan zakat, manfaat zakat, perbedan zakat mal dan zakat fitrah. Tugas siswa adalah melakukan investigasi menggunakan sumber elektronik atau buku-buku di perpustakaan. Berdasar pengalaman peneliti di lapangan, siswa merasa bahagia menjalani fase ini karena mereka tidak dipaksa untuk menghafal, tapi berusaha menemukan sendiri.

Ketiga, mengajukan hipotesis atau jawaban sementara, yaitu peneliti memberi perintah kepada siswa untuk menyusun hipotesis terkait dengan masalah yang diberikan. Cara menyusun hipotesis adalah siswa berdiskusi dengan teman untuk merumuskan spekulasi-spekulasi terkait dengan masalah yang disajikan. Dalam menyusun spekulasi tersebut, siswa berdiskusi secara panas, karena masing-masing orang memiliki pendapatnya sendiri-sendiri. Melalui pembelajaran seperti ini, suasana kelas menjadi lebih menarik daripada sekedar ceramah.

Keempat, mengumpulkan data, yaitu siswa menjaring informasi untuk menguji 
hipotesis yang diajukan. Kegiatan siswa adalah menguji hipotesis dengan cara melakukan investigasi melalui study literature di internet (electronic resources) atau buku di perpustakaan. Berdasar investigasi mereka, siswa mampu menjawab bahwa zakat hukumnya wajib, sementara sedekah hukumnya sunnah. Adapun tujuan dari zakat adalah untuk mensucikan harta dari yang subhat dan haram. Zakat mal adalah zakat yang harus dikeluarkan setiap tahun setelah mencapai nisab, sementara zakat fitrah dikeluarkan pada bulan ramadhan sebelum idul fitri. Ketika menjalani fase ini, siswa merasa puas dan bahagia karena mereka berusaha memecahkan masalah secara mandiri.

Kelima, peneliti mengumpulkan informasi dari hasil investigasi siswa, lalu mendorong siswa untuk menguji hipotesis yang dikumpulkan. Peneliti mengajak siswa untuk melakukan kritik sumber terkait dari hasil yang peroleh di fase investigasi. Berikutnya, peneliti bersama siswa mencari data teoritik untuk menentukan kebenaran dari rumusan hipotesis. Adapun tugas siswa adalah menarik kesimpulan dari diskusi yang dilakukan.

Keenam, merumuskan kesimpulan, yaitu proses mendeskripsikan temuan yang diperoleh berdasar hasil pengujian hipotesis. Peneliti memberi perintah kepada siswa untuk merumuskan kesimpulan berdasar data yang diperoleh melalui investigasi. Pada fase ini, siswa merasa puas dengan hasil capaian mereka, karena pada akhirnya, mereka menemukan solusi atas permasalahan yang disajikan. Penelitian ini menemukan, kebermaknaan pengetahuan yang diperoleh dengan cara ini memiliki akurasi lebih tinggi dari pengetahuan yang disampaikan lewat ceramah.

Berdasar studi kasus di atas, peneliti menemukan bahwa, metode pembelajaran inquiry mampu menjadi solusi bagi pendidikan Agama Islam yang selama ini hanya berkutat pada hafalan teks suci. Metode inquiry mampu meningkatkan akurasi kebermaknaan pengetahuan yang dimiliki siswa. Metode pendidikan seperti ini seharusnya terus dikembangkan untuk memajukan pendidikan, sehingga siswa mampu melakukan pemecahan masalah secara mandiri.

\section{KESIMPULAN}

Inquiry learning menekankan pengembangan aspek kognitif, afektif dan psikomotorik secara berimbang, sehingga dapat memberi ruang bagi siswa untuk belajar sesuai keinginan mereka. Penelitian ini menemukan bahwa, inquiry adalah metode pembelajaran yang dibutuhkan oleh mata pelajaran pendidikan Agama Islam saat ini yang mengalami krisis sebagai mata pelajaran yang dianggap tidak penting di sekolah umum. Dengan demikian, hadirnya metode inquiry dalam pembelajaran pendidikan Agama Islam diharapkan mampu mengembangkan pendidikan agama Islam, sehingga tidak lagi didiskriminasikan, dan menjadi mata pelajaran inti, karena mengajarkan budi pekerti. Budi pekerti seharusnya menjadi spirit bagi seluruh mata pelajaran karena ilmu tidak ada artinya tanpa budi pekerti. Secara operasional, inquiry dapat diaktualisasikan dalam beberapa langkah, yaitu: orientasi, merumuskan masalah, mengajukan hipotesis, mengumpulkan data, menguji hipotesis dan merumuskan kesimpulan. Dengan langkah operasional ini, mata pelajaran pendidikan Agama Islam tidak lagi menjadi mata pelajaran yang terlalu banyak menghafal, tapi lebih banyak praktik. Dengan demikian, mata pelajaran Agama Islam tidak lagi menjadi mata pelajaran yang membosankan, tapi menyenangkan dan efektif.

\section{DAFTAR PUSTAKA}

Chu, Samuel Kai Wah. Rebecca B. Reynolds, dkk, (2017) 21st Century Skills Development Through Inquiry-Based Learning From Theory to Practice. Singapore: Springer Nature.

Darmansyah. (2010) Strategi Pembelajaran Menyenangkan dengan Humor. Jakarta Bumi Aksara.

Djajadisastra. (1981) Metode-Metode Mengajar. Bandung: Angkasa. 
Hamruni. (2009) Strategi dan Model-Model Pembelajaran Aktif Menyenangkan, Yogyakarta, Fakultas Tarbiyah UIN Sunan Kalijaga.

Healey, Mick. (2005) Linking Research and Teaching: Exploring Disciplinary Spaces And The Role Of Inquiry-Based Learning. Reshaping the University: New Relationships between Research, Scholarship and Teaching.

Higgins, Joanna. Ro Parsons, and Linda Bonne. (2011) Processes of Inquiry: Inservice Teacher Educators Research Their Practice. The Netherlands: Sense Publishers.

Kholilah, Lilah (2019) Pengaruh Penggunaan Model Pembelajaran Inquiry Pada Mata Pelajaran Pendidikan Agama Islam Terhadap Keterampilan Berpikir Dan Kemandirian Belajar Peserta Didik Kelas VII di SMP Negeri Unggulan Sindang Kabupaten Indramayu, OASIS: Jurnal Ilmiah Kajian Islam, vol. 4, no. 1, p. 1-14. From https://syekhnurjati.ac.id/jurnal/index.php/oasis/article/view/4220

Kuhlthau, Carol C., Leslie K. Maniotes, dan Ann K. Caspari. (2007) Guided Inquiry: Learning in the 21 st Century. United States of America: Libraries Unlimited.

Majajareng. (2021) Penerapan Model Inquiry Learning Untuk Meningkatkan Hasil Belajar Pendidikan Agama Islam Kelas 6 SD Negeri 4 Ratolindo. Lentera Pendidikan Indonesia: Jurnal Media, Model, Dan Pengembangan Pembelajaran, 2(3), p. 147-154. From http://lingkarpenaindonesia.com/e-journal/index.php/lpi/article/view/43

Muhaimin. (1996) Rekonstruksi Pendidikan Islam. Jakarta : Raja Grafindo.

Muhaimin. (2009) Strategi Belajar Mengajar. Surabaya: CV Citra media.

Mulyasa. (2008) E. Menjadi Guru Profesional Menciptakan Pembelajaran Kreatif dan Menyenangkan. Bandung : PT Remaja Rosda Karya.

N., Suryani, \& Agung, L. (2012) Strategi Belajar-Mengajar. Yogyakarta: Ombak.

Newell, R. J. Passion for learning. (2003) How project-based learning meets the needs of $21^{\text {st }}$ Century Student. The Scarecrow Press: Lanham, Maryland, and Oxford.

Novak, Alfred. (1964) "Scientific Inquiry", BioScience, vol. 14, no. 10, p. 25-28. From https://academic.oup.com/bioscience/article-abstract/14/10/25/219079

Nurhadi \& A. G Senduk. (2004) Pembelajaran kontekstual (CTL) Dan Penerapannya dalam KBK. Malang: Universitas Negeri Malang.

Reinhardt, Jill Y. (2014) Improving Classroom Practice Through Collaborative Inquiry: A Case Of Flipped Learning. The University of North Carolina at Greensboro.

Roestiyah. (1991) Strategi Belajar Mengajar. Jakarta : PT. Rineka Cipta.

Sanjaya, Wina. (2011) Strategi Pembelajaran Berorientasi Standar Proses Pendidikan. Jakarta: Kencana.

Sariah, (2017) Implementasi Pembelajaran Inquiry Pada Bidang Studi Aqidah Akhlak. Potensia: Jurnal Kependidikan Islam. vol. 3, no. 1, p. 105-121. From http://ejournal.uin-suska.ac.id/index.php/potensia/article/view/3489

Slameto. (1993) Proses Belajar Mengajar Dalam Proses Kredit Semester SKS. Jakarta: Bumi Aksara.

Solichin, Mohammad Muchlis. (2017) Penerapan Model Pembelajaran Inquiry Discovery dalam Pendidikan Agama Islam. Tadris: Jurnal Pendidikan Islam, vol. 12, no. 2, From http://103.162.55.7/index.php/tadris/article/view/1580

Sunaryo. (1989) Strategi Belajar Mengajar Ilmu Pengetahuan Sosial. Malang: IKIP Malang.

Wells, Alison. (2011) Inquiry-Based Learning: Fact or Fallacy? Manitoba: University of Manitoba.

Won, Mihye. (2009) Issues In Inquiry-Based Science Education Seen Through Dewey's Theory Of Inquiry. Urbana-Champaign: University of Illinois. 